\title{
Development and Validation of a RP-HPLC Method for the Simultaneous Estimation of Sulfadoxine and Pyrimethamine in Combined Dosage Tablets
}

\author{
Sanjay Pai PN, Cynella Dias and Neelam Sawant \\ Department of Pharmaceutical Analysis, Goa College of Pharmacy, 18 th June Road, Panjim-403001, Goa, INDIA.
}

\begin{abstract}
A new simple, sensitive and reproducible RP-HPLC method for the simultaneous estimation of sulfadoxine and pyrimethamine in pharmaceutical formulations was developed and validated. The separation was carried out on Zorbax Eclipse Plus C18, $3.5 \mu \mathrm{m}(4.6 \times 100 \mathrm{~mm})$ column with acetonitrile: $20 \mathrm{mM}$ sodium acetate buffer $\mathrm{pH}$, $80: 20 \% \mathrm{v} / \mathrm{v}$ as the mobile phase at the flow rate of $1 \mathrm{ml} / \mathrm{min}$. The eluent detection was carried out using UV-Visible PDA detector at $224 \mathrm{~nm}$. The retention time of sulfadoxine and pyrimethamine was $0.9 \mathrm{~min}$ and $1.2 \mathrm{~min}$ respectively. Linearity was observed for sulfadoxine and pyrimethamine in the concentration range of $60-200 \mu \mathrm{g} / \mathrm{ml}$ and $3-10 \mu \mathrm{g} / \mathrm{ml}$ respectively. The recovery of sulfadoxine and pyrimethamine was found to be $97.21-98.56 \%$ and $96.90-97.26 \%$ respectively.
\end{abstract}

Key words: RP-HPLC, Sulfadoxine, Pyrimethamine, Validation, Stress-induced stability.

\section{INTRODUCTION}

Sulfadoxine has been widely used in the treatment of various infections, such as cholera, leprosy, malaria and paracoccidioidomycosis. In combination with pyrimethamine, it is used in the treatment and prophylaxis of falciparum malaria resistant to other chemotherapeutic agents. ${ }^{1}$ Pyrimethamine is a potent inhibitor of DHFR. The drug has shown to have a significantly higher affinity for binding to the DHFR of plasmodium than to the host enzyme (>1000 times in Plasmodium berghei) and, as a result, has been used to selectively treat plasmodium infections. The combination of pyrimethamine with a long acting sulfonamide, sulfadoxine, which blocks dihydrofolate synthesis by preventing incorporation of PABA into the dihydrofolate. The site of action of this combination is in the cytosol of plasmodium. The drug combination appears to have improved drug mediated disruption of folic acid in Plasmodium sp. The combination has been used with quinine for prevention and treatment of chloroquine resistant malaria. The combination therapy has the added advantage of being inexpensive which is essential for successful therapy in developing countries. ${ }^{2}$ Both the drugs are official in Indian Pharmacopoeia, ${ }^{3}$ British Pharmacopoeia ${ }^{4}$ and United States Pharmacopoeia. ${ }^{5}$ Chemically sulfadoxine is $\mathrm{N}^{1}$-(5,6-dimethoxypyrimidin-4-yl)- sulphanilamide (Figure 1) and pyrimethamine is 5-(4-chlorophenyl)-6-ethylpyrimidine2,4-diamine (Figure 2). On review of literature a few spectrophotometric, ${ }^{6-7}$ LC-MS ${ }^{8-10}$ and RP-HPLC ${ }^{11-17}$ methods for the estimation of sulfadoxine and pyrimethamine in combination have been reported. As found from the literature sulfadoxine has been reported to be estimated in combination with other drugs by HPLC. ${ }^{18-19}$ Pyrimethamine has also been reported to be estimated by HPLC methods in tablets and in plasma. ${ }^{20-22}$ The reported methods were reviewed. The first
Submission Date : 19-02-2016 Revision Date : :05-04-2016 Accepted Date : :27-04-2016

DOI: 10.5530/ijper.50.3.24 Correspondence: Sanjay Pai PN,

Department of Pharmaceutical Analysis, Goa College of Pharmacy, 18th June Road, Panjim-403001, Goa, INDIA. Mobile: 9448207428 Telephone: 0832-2226882 Fax: 0832-2226883 Email: pnsanjaypai@gmail. com

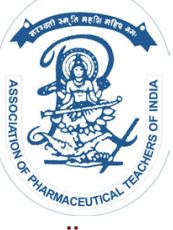

www.ijper.org 
method $^{12}$ uses Kromasil C18, $5 \mu(250 \times 4.6 \mathrm{~mm})$ column with methanol, acetonitrile and $0.1 \%$ orthophosphoric acid in ratio 10:50:40, flow rate $1 \mathrm{ml} / \mathrm{min}$ at $223 \mathrm{~nm}$, retention time were $4.67 \mathrm{~min}$ and $6.74 \mathrm{~min}$ for sulfadoxine and pyrimethamine respectively. The second method $^{16}$ uses Xbridge C18, $5 \mu(100 \times 4.6 \mathrm{~mm})$ column with phosphate buffer: ACN 80:20 as mobile phase, flow rate $1 \mathrm{ml} / \mathrm{min}$ at $223 \mathrm{~nm}$, retention time was found to be $4.3 \mathrm{~min}$ for sulfadoxine and $6.3 \mathrm{~min}$ for pyrimethamine respectively. The third method ${ }^{17}$ uses ODS column with phosphate buffer of $\mathrm{pH}$ 3.2: $\mathrm{ACN}, 70: 30$ as mobile phase, flow rate $1 \mathrm{ml} / \mathrm{min}$, retention time was found to be $4.1 \mathrm{~min}$ and $5.8 \mathrm{~min}$ for sulfadoxine and pyrimethamine respectively. For the reported methods phosphate buffers have been commonly used for the analysis of the sulfadoxine-pyrimethamine combination and retention times have been consistently found between 4 to $6 \mathrm{~min}$. The objective of the present work was to develop a simultaneous method for the determination of sulfadoxine and pyrimethamine in combination with volatile buffer like acetate buffer for possible LCMS analysis, validate the method and apply the same for estimation of marketed formulation.

\section{MATERIAL AND METHODS}

\section{Equipment}

HPLC of Agilent 1260 make equipped with autosampler and auto injector with PDA detector and Double beam UV/VIS spectrophotometer of Lab India ${ }^{\circledR}$ make of UV $3000^{+}$Analytical Tech model were used for the study. Sulfadoxine and pyrimethamine reference standards were obtained from R L FineChem, Bangalore. Combined tablet dosage formulations as Falcigo-SP Kit from Aeon formulations Pvt. Ltd and Larinate-100 Kit from Ipca laboratories Ltd. containing $500 \mathrm{mg}$ of sulfadoxine and $25 \mathrm{mg}$ of pyrimethamine per tablet were purchased from the local market. HPLC grade acetonitrile and water was procured from Merck Specialities Private Limited, Mumbai. Sodium acetate and glacial acetic acid (AR grade) was obtained from Loba Chemie Pvt. Ltd. and Molychem, Mumbai respectively.

\section{Chromatographic conditions}

Zorbax Eclipse Plus C18, 3.5 m (4.6×100 mm) column was used for the separation. Acetonitrile: $20 \mathrm{mM}$ sodium acetate buffer $\mathrm{pH} 6,80: 20 \% \mathrm{v} / \mathrm{v}$ was delivered at a flow rate of $1 \mathrm{ml} / \mathrm{min}$ and detection carried out at $224 \mathrm{~nm}$. The injection volume was $5 \mu \mathrm{l}$ and the analysis was performed at ambient temperature.

\section{Standard stock solution}

Std stock solution of sulfadoxine and pyrimethamine were prepared separately in mobile phase of concentration $1000 \mu \mathrm{g} / \mathrm{ml}$ and $100 \mu \mathrm{g} / \mathrm{ml}$ respectively. Working std solution was prepared by mixing $1.3 \mathrm{ml}$ of sulfadoxine and $6.5 \mathrm{ml}$ of pyrimethamine std stock solutions in $10 \mathrm{ml}$ std flask, diluted with the mobile phase to the mark. The retention time of sulfadoxine and pyrimethamine were found to be $0.9 \mathrm{~min}$ and $1.2 \mathrm{~min}$, respectively. Calibration curves were constructed by plotting the average peak areas against the respective concentrations and found to be linear in the range of $60-200 \mu \mathrm{g} / \mathrm{ml}$ and $3-10 \mu \mathrm{g} / \mathrm{ml}$ for sulfadoxine and pyrimethamine respectively, $\mathrm{r}^{2}$ being 0.999 for both the drugs.

\section{Analysis of sulfadoxine and pyrimethamine in marketed tablets}

Twenty tablets were accurately weighed and finely powdered. An amount of tablet powder equivalent to $100 \mathrm{mg}$ of sulfadoxine was transferred into a $100 \mathrm{ml}$ std flask. About $50 \mathrm{ml}$ of mobile phase was added to the flask and sonicated for 15 min to disperse the contents completely. The volume was made up to the mark with the mobile phase and filtered using Whatman filter paper (no. 45) to obtain sample stock solution. From this $1.3 \mathrm{ml}$ was transferred into a $10 \mathrm{ml}$ calibrated std flask and volume made up with the mobile phase to obtain working sample solution.

\section{VALIDATION}

The method was validated for linearity, precision, specificity, accuracy, ruggedness and robustness as per the ICH guidelines. ${ }^{23}$ The linearity for sulfadoxine and pyrimethamine was found to be in the range of 60-200 $\mu \mathrm{g} / \mathrm{ml}$ and $3-10 \mu \mathrm{g} / \mathrm{ml}$ respectively. Accuracy was determined at three different levels of $80 \%, 100 \%$ and $120 \%$ of the target concentration of the active ingredient, by adding a known amount of each std to previously analysed tablet sample. Precision was studied to determine intraday variation by performing six replicate assays of the tablet sample. The $\%$ RSD was calculated for intraday precison. The LOD and LOQ were calculated from the standard calibration curves. The residual standard deviation of the regression line or the standard deviation of the y-intercepts of regression lines was used as the standard deviation. LOD and LOQ were calculated with equations $\mathrm{LOD}=3.3 \sigma / \mathrm{S}$ and $L O Q=10 \sigma / S$; where, $\sigma$ is the Standard deviation of the response and $\mathrm{S}$ is the slope of the calibration curve. Robustness of the method was determined by making slight changes in the operating conditions viz. 


\begin{tabular}{|c|c|c|}
\hline Parameters & Sulfadoxine & Pyrimethamine \\
\hline Theoretical plates & 2261 & 3020 \\
\hline Resolution & \multicolumn{2}{|c|}{3.2} \\
\hline Asymmetric factor & 1.19 & 1.03 \\
\hline Retention Time (min) & 0.9 & 1.2 \\
\hline Linearity range $(\mu \mathrm{g} / \mathrm{ml})$ & $60-200$ & $3-10$ \\
\hline $\begin{array}{l}\text { Regression Equation } \\
\qquad y=m x+c\end{array}$ & $y=1263660.624 x+3916998.722$ & $y=2742921.802 x+1489716.623$ \\
\hline Slope (m) & 1263660.624 & 2742921.802 \\
\hline Intercept (c) & 3916998.722 & 1489716.623 \\
\hline Correlation coefficient & 0.999 & 0.999 \\
\hline Intra day(n 6) \% RSD & 0.28 & 0.33 \\
\hline $\operatorname{LOD}(\mu \mathrm{g} / \mathrm{ml})$ & 5.93 & 0.33 \\
\hline $\mathrm{LOQ}(\mu \mathrm{g} / \mathrm{ml})$ & 17.99 & 1.018 \\
\hline
\end{tabular}

*Average of six determination, $y$ is the area under curve and $x$ is the concentration, RSD is the relative standard deviation, LOD- Limit of detection, LOQ- Limit of Quantitation.

\begin{tabular}{|c|c|c|c|c|}
\hline \multirow{5}{*}{ Parameters } & Proposed & Variation & Sulfadoxine & Pyrimethamine \\
\cline { 3 - 5 } & & & \multicolumn{3}{|c|}{$\%$ Assay } \\
\hline \multirow{2}{*}{ Flow rate } & $1.0 \mathrm{ml} / \mathrm{min}$ & $0.8 \mathrm{ml} / \mathrm{min}$ & 100.74 & 99.74 \\
\cline { 3 - 5 } & & $1.2 \mathrm{ml} / \mathrm{min}$ & 96.05 & 97.71 \\
\hline \multirow{2}{*}{$\begin{array}{c}\text { Mobile phase } \\
\text { composition }\end{array}$} & \multirow{2}{*}{$\mathrm{80:20 \%}$} & $75: 25 \%$ & 97.45 & 93.93 \\
\hline \multirow{2}{*}{$\mathrm{pH}$} & & $85: 15 \%$ & 96.06 & 98.57 \\
\cline { 3 - 5 } & \multirow{2}{*}{6.0} & 5.8 & 102.1 & 101.5 \\
\cline { 3 - 5 } & & 6.2 & 95.87 & 96.1 \\
\hline
\end{tabular}

\begin{tabular}{|c|c|c|c|c|c|c|}
\hline \multicolumn{4}{|c|}{ Sulfadoxine } & \multicolumn{3}{|c|}{ Pyrimethamine } \\
\hline $\begin{array}{l}\text { Level of std } \\
\text { addition(\%) }\end{array}$ & $\begin{array}{l}\text { Amount present } \\
\text { in sample }(\mu \mathrm{g} / \mathrm{ml})\end{array}$ & $\begin{array}{l}\text { Amount of std } \\
\text { added }(\mu \mathrm{g} / \mathrm{ml})\end{array}$ & $\%$ Recovery* & $\begin{array}{l}\text { Amount present in } \\
\text { sample } \\
(\mu \mathrm{g} / \mathrm{ml})\end{array}$ & $\begin{array}{c}\text { Amount of } \\
\text { std added } \\
(\mu \mathrm{g} / \mathrm{ml})\end{array}$ & $\%$ Recovery* \\
\hline 80 & \multirow{3}{*}{130} & 104.0 & 98.563 & \multirow{3}{*}{6.5} & 5.2 & 97.263 \\
\hline 100 & & 130.0 & 97.609 & & 6.5 & 96.900 \\
\hline 120 & & 156.0 & 97.208 & & 7.8 & 97.264 \\
\hline
\end{tabular}

*Average of three determinations.

flow rate $\pm 0.2 \mathrm{ml}$, change in the organic phase ratio by $\pm 5 \%$ and $\mathrm{pH}$ by \pm 0.2 units. Specificity was determined using a placebo of commonly used tablet excipients. The solution stability was determined by performing the analysis up to $12 \mathrm{hr}$ with the working solutions. The mixed standard solutions of sulfadoxine and pyrimethamine were then subjected to stress studies under acid and base hydrolysis conditions by refluxing with $0.1 \mathrm{M}$ hydrochloric acid and $0.1 \mathrm{M}$ sodium hydroxide solutions for $3 \mathrm{hr}$ separately. Also both the standard substances as solids was subjected to high temperature of $80^{\circ} \mathrm{C}$ for
$3 \mathrm{hr}$ and exposure to UV radiation for $1 \mathrm{hr}$. The resulting solutions were assayed by the validated process.

\section{RESULTS AND DISCUSSION}

The aim of the present study was to develop a rapid and precise RP-HPLC method for the estimation of sulfadoxine and pyrimethamine in combined dosage form, with volatile buffers and validate in accordance with ICH guidelines. Exploratory trials were performed in order to select adequate and optimum conditions to 
<smiles>COc1ncnc(NS(=O)(=O)c2ccccc2)c1OC</smiles>

Figure 1: Chemical Structure of Sulfadoxine.

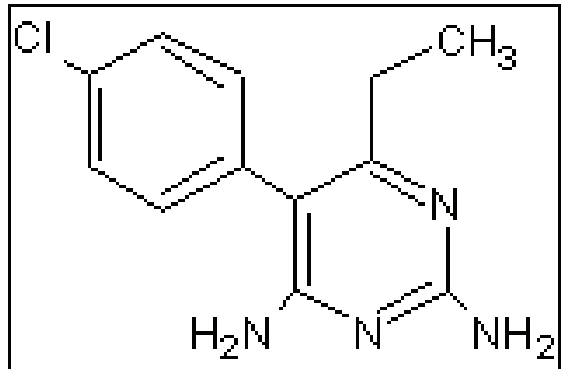

Figure 2: Chemical Structure of Pyrimethamine.

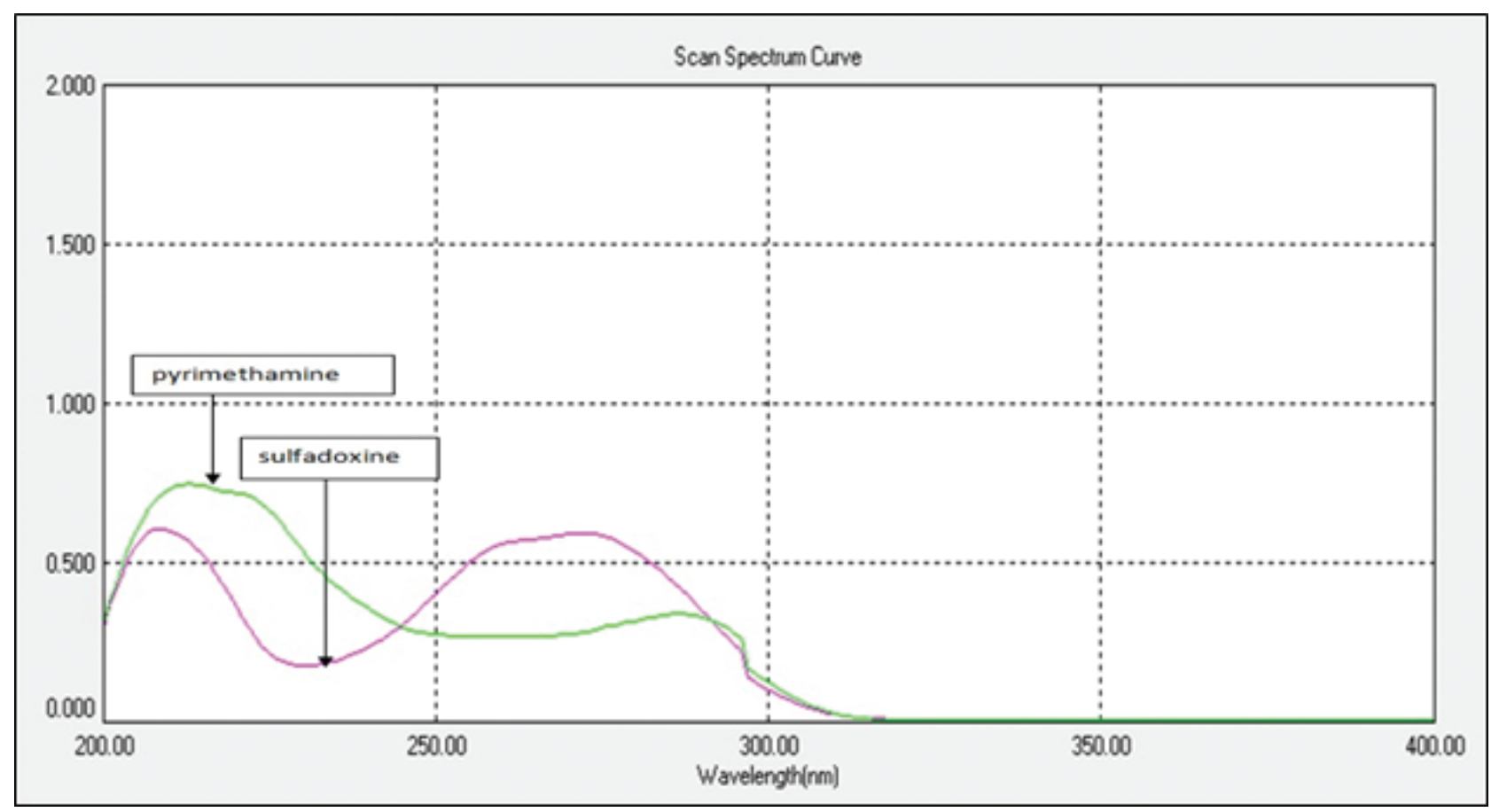

Figure 3: Overlay UV spectrum of sulfadoxine and pyrimethamine in optimized mobile phase.

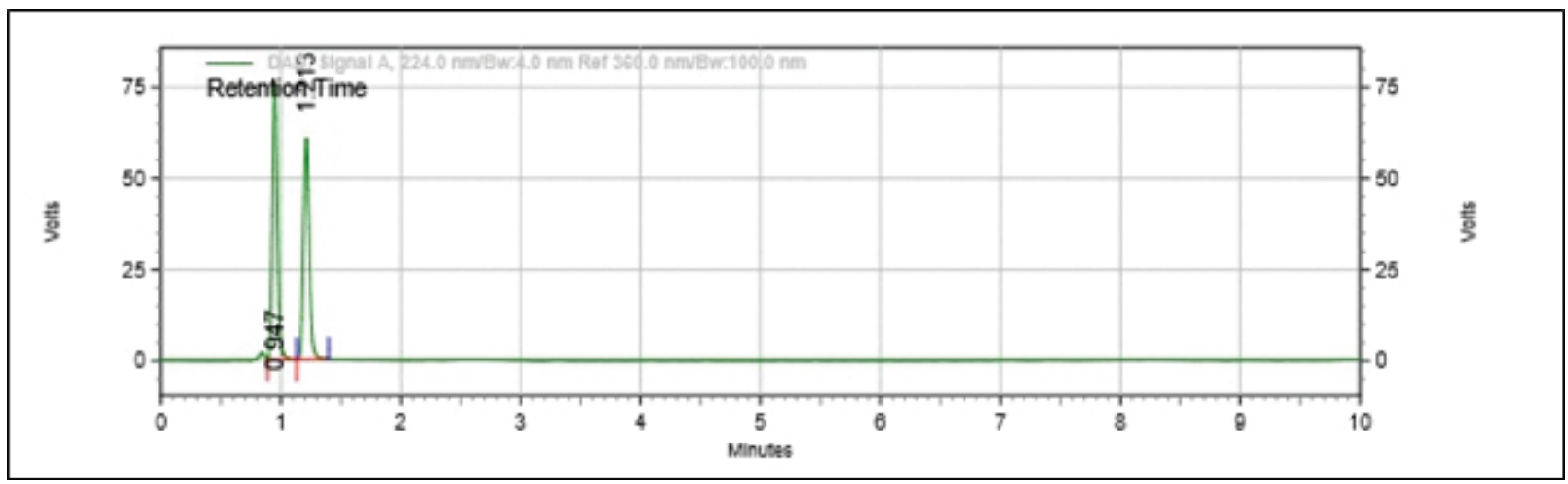

Figure 4: Typical chromatogram showing separation of sulfadoxine and pyrimethamine in combined dosage dosage form. 
develop an effective method. UV overlain spectra of both sulfadoxine and pyrimethamine showed that both the drugs absorb appreciably at $224 \mathrm{~nm}$ (Figure 3). As concentration of sulfadoxine is much higher than pyrimethamine in marketed dosage form in the ratio of 20:1, a wavelength suitable for detection of both in such disproportionate ratio was possible at $224 \mathrm{~nm}$, wherein absorbance was higher for pyrimethamine in comparison to sulfadoxine by significant folds for solutions of matching concentration. The mobile phase containing acetonitrile: $20 \mathrm{mM}$ sodium acetate buffer $\mathrm{pH}$ 6.0, $80: 20 \%$ with a flow rate of $1 \mathrm{ml} / \mathrm{min}$ was selected for analysis after preliminary studies. The retention time of sulfadoxine and pyrimethamine was $0.9 \mathrm{~min}$ and $1.2 \mathrm{~min}$ respectively. Resolution of the method was found to be 3.2 , which is highly satisfactory and indicates good separation of compound peaks.

Typical chromatogram of sulfadoxine and pyrimethamine is shown in Figure 4. The system suitability tests were carried out and parameters are summarized in Table 1 . The tailing factor was calculated statistically and found to be 1.19 and 1.03 for sulfadoxine and pyrimethamine respectively. The standard calibration curves for the drug mixtures were plotted and the linearity range obtained was $60-200 \mu \mathrm{g} / \mathrm{ml}$ for sulfadoxine and 3-10 $\mu \mathrm{g} / \mathrm{ml}$ for pyrimethamine. Linearity coefficient and percentage curve fitting were well within the limits as found from the value of 0.999 and 0.999 for sulfadoxine and pyrimethamine respectively. The \% RSD of assay was found to be within limit of $2 \%$ (Table 1), indicating high degree of precision and reproducibility. There was no visible peak in the retention time upto 10 min indicating high degree of specificity of the proposed method. Accuracy was determined through recovery study of the drug at three levels ranging from $80-120 \%$ and was found to be well within the acceptance limit indicating no interferences of the drug with each other nor with the excipients present in the formulation (Table 3).

The robustness of the method (Table 2) was determined by carrying out the assay by slightly varying the mobile phase ratio, $\mathrm{pH}$ and flow rate and the percentage recovery was found to be within limits (Table 3). The detection limit was found to be $5.93 \mu \mathrm{g} / \mathrm{ml}$ for sulfadoxine and $0.33 \mu \mathrm{g} / \mathrm{ml}$ for pyrimethamine while the quantitation limit was found to be $17.99 \mu \mathrm{g} / \mathrm{ml}$ for sulfadoxine and $1.01 \mu \mathrm{g} / \mathrm{ml}$ for pyrimethamine which suggests that the amount of both the compounds can be estimated accurately.

It was observed that the retention time and peak area of all the working standard and sample solutions remained unchanged and no significant degradation observed up to $12 \mathrm{hr}$. For stress stability studies, the peak positions remained constant and peak area response did not alter by more than $2 \%$ indicating stability of sulfadoxine and pyrimethamine under all the stress conditions. So the proposed method is specific, reproducible and accurate for the analysis of sulfadoxine and pyrimethamine in combined dosage form.

\section{CONCLUSION}

A new RP-HPLC method for the simultaneous estimation of sulfadoxine and pyrimethamine in pharmaceutical formulations was developed using simple acetate based mobile phase on a C-18 ODS column of $10 \mathrm{~cm}$ length. Separation was complete with shorter analysis time compared to reported methods with $25 \mathrm{~cm}$ ODS column with non-volatile phosphate buffers. The method was accurate and found to be simple, specific, reproducible, precise and robust.

\section{ACKNOWLEDGEMENT}

The authors would like to thank RL Fine Chemicals, Bengaluru, India for providing Reference standards of sulfadoxine and pyrimethamine as Gift samples.

\section{CONFLICT OF INTEREST}

Authors declare no conflict of interest.

\section{ABBREVIATIONS USED}

Std: Standard

ICH: International Conference on Harmonisation.

\section{SUMMARY}

- RP-HPLC method for simultaneous analysis of sulfadoxine and pyrimethamine in tablet formulation was developed and validated on Zorbax Eclipse plus C 18, $3.5 \mu \mathrm{m}(4.6 \times 100 \mathrm{~mm})$ column.

- Mobile phase composition acetonitrile: $20 \mathrm{mM}$ sodium acetate buffer $\mathrm{pH} 6$ in the ratio 80:20\% v/v at flow rate of $1 \mathrm{ml} / \mathrm{min}$ provided low net retention times with good resolution. 


\section{REFERENCES}

1. Korolkovas A. Anti-infective agents. In: Essentials of Medicinal Chemistry, $2^{\text {nd }}$ ed. USA: John Wiley and Sons; 2008. p.710

2. Lemke TL. Antiparasitic agents. In: Lemke TL, editor. Foye's principles of Medicinal Chemistry, $7^{\text {th }}$ ed. China: Lippincott Williams and Wilkins; 2013. p.1143

3. Indian Pharmacopoeia. The Indian Pharmacopoeia Commission. Ghaziabad: Govt. of India Ministry of Health and Family Welfare; 2014. 3. p. 2602-3, 2807.

4. British Pharmacopoeia. The Stationery Office on behalf of the Medicines and Healthcare products Regulatory Agency (MHRA). Great Britain: The Department of Health; 2013. p. 1905-6, 2124.

5. United States Pharmacopoeia. Rockville: United States Pharmacopoeial Convention, Inc; 2013. Vol. 3. p. 4980-1, 5221-2.

6. Meena S, Sandhya M. Validated spectrophotometric methods for simultaneous analysis of pyrimethamine and sulphadoxine in pharmaceutical dosage forms. Asian J of Pharm and Clin Res 2013;6(3):121-3. http:// innovareacademics.in/journals/index.php/ajpcr/article/view/296

7. Patel KN, Patel JK. Spectrophotometric Methods for Simultaneous Estimation Of Pyrimethamine And Sulphadoxine In Bulk Drug And Pharmaceutical Formulations. [homepage on the Internet]. 2014 [cited 2016 Jan 27]. Available from: http://www.pharmatutor.org/articles/spectrophotometricmethods-for-simultaneous-estimation-of-pyrimethamine-and-sulphadoxinein-bulk-drug-pharmaceuticals

8. Sandhya SM, Shijikumar PS. A Simplified Liquid Chromatography-Mass Spectrometry Method for Simultaneous Determination of Pyrimethamine, Sulphadoxine and Artesunate in Human Plasma. J App Pharm Sci.2015;5:109-14. http://www.japsonline.com/abstract.php?article_id=1539

9. Hodel EM, Zanolari B, Mercier T, Biollaz J. Keiser J. Olliaro P. et al. A single LC-tandem mass spectrometry method for the simultaneous determination of 14 antimalarial drugs and their metabolites in human plasma. J Chrom B Analyt Tech Biomed Life Sci. 2009;877(10):867-86. http://dx.doi. org/10.1016/j.jchromb.2009.02.006PMid:19249251

10. Sabarinath S, Singh RP, Gupta RC. Simultaneous quantification of alpha-/ beta-diastereomers of arteether, sulphadoxine and pyrimethamine: a promising anti-relapse antimalarial therapeutic combination, by liquid chromatography tandem mass spectrometry. J Chrom B Analyt Tech Biomed Life Sci. 2006;842(1):36-42. http://dx.doi.org/10.1016/j.jchromb.2006.05.003; PMid:16725391

11. Bergqvist $\mathrm{Y}$, Eckerbom S, Larsson H, Malekzadeh M. Reversed-phase liquid chromatographic method for the simultaneous determination of the antimalarial drugs sulfadoxine, pyrimethamine, mefloquine and its major carboxylic metabolite in plasma. J Chrom. 1991;571(1):169-77. http://www. ncbi.nlm.nih.gov/pubmed/1810945; http://dx.doi.org/10.1016/0378-4347(91) 80443-G

12. Kumari MK, Kasthuri JK, Babu BH, Satyanarayana PVV. A validated liquid chromatographic method for the determination of sulfadoxine and pyrimethamine in pharmaceutical formulations. World $\mathrm{J}$ of Pharm and Pceut Sci 2014;3:1032-4. http://www.wjpps.com/download/article/1413443737.pdf
13. Eljaschewitsch J, Padberg J, Schürmann D, Ruf B. High-performance liquid chromatography determination of pyrimethamine, dapsone, monoacetyldapsone, sulfadoxine, and $\mathrm{N}$-acetyl-sulfadoxine after rapid solidphase extraction. The Drug Monit1996 18(5):592-7. http://bvs.sld.cu/revistas/ far/vol46_3_12/far04312.htm

14. Mohammed SA, Sultana N, Siddiqui FA, Naseem S, Qureshi F. Simultaneous determination of pyrimethamine, sulfadoxine, mefloquine, and ibuprofen in pharmaceutical formulations by RP-HPLC. Med Chem Res 2009;19(9):1043-54. http://link.springer.com/article/10.1007\%2Fs00044-009-9250-4

15. Fernandez MM, Vidal ALP, Lopez CA, TrujilloSB. Validation of a liquid chromatographic method for determination of sulphadoxine and pyrimethamine in whole blood spotted on filter paper. Revista Cubana de Farmacia 2012;46(3):311-9. http://scielo.sld.cu/scielo.php?script=sci arttext\&pid=S0034-75152012000300004

16. Vemula RVB, Sharma PK, Singhvi I. HPLC Method Development and Validation For Simultaneous estimation of Sulphadoxine and Pyrimethamine In Tablet Dosage Form. Int J Pharm Sci 2013;3:295-8. http://ijps. aizeonpublishers.net/content/2013/4/ijps295-298.pdf

17. Nataraj KS, Chaitanya K, Alekhya K, Babu BS, Gnananath K. Simultaneous estimation of sulfadoxine and pyrimethamine by using RP-HPLC in bulk and tablet dosage form. Int J Environ Chem Chromat 2015;18-14.

18. Gbotosho OG, Christian TH, Abayomi OS, Akin S, Ayoade MJO.A simple costeffective high performance liquid chromatographic assay of sulphadoxine in whole blood spotted on filter paper for field studies. Malaria Journal 2009;8(1):238. http://dx.doi.org/10.1186/1475-2875-8-238 ; PMid:19852850 PMCid:PMC2773786

19. Dua VK, Gupta NC, Sethi P, Edwards G, Dash AP. High-performance liquid chromatographic assay for the determination of sulfadoxine and $\mathrm{N}$-acetyl sulfadoxine in plasma from infected patients with sensitive and resistant Plasmodium falciparum malaria. J Chrom B 2007;860(2):160-5. http://dx.doi. org/10.1016/j.jchromb.2007.10.016; PMid:17997367

20. Timm U, Weidekamm E. Determination of pyrimethamine in human plasma after administration of fansidar or fansidar-mefloquine by means of highperformance liquid chromatography with fluorescence detection. J Chrom. 1989;230(1):107-14. http://www.ncbi.nlm.nih.gov/pubmed/2584319; http:// dx.doi.org/10.1016/S0378-4347(00)81435-8

21. Zytkovicz TH, Salter J, Hennigan L, Timperi R, Maguire J, Hoff R,et al. Isocratic Reversed-Phase HPLC method to Measure Pyrimethamine Extracted from Plasma of Infants Treated for Toxoplasmosis. Clin.Chem. 1991;37(7):1281-3. www.ncbi.nlm.nih.gov/pubmed/1855303

22. Guenzi A, Cappelletti G, Scala A, Zanetti M. Simultaneous determination of pyrimethamine and mefloquine in human plasma by high-performance liquid chromatography with ultraviolet detection. J Chrom. 1989;494:219-30. www. ncbi.nlm.nih.gov/pubmed/2584319

23. Guidance for industry, Q2 (R1) validation of Analytical Procedures: Methodology, U.S. Department of Health and Human Services, Food and drug administration, Centre for Drug evaluation and Research (CDER), centre for Biologics Evaluation and Research (CBER), International Conference on Harmonization, Geneva, November 2005. 